\title{
The 1886 Yoruba Peace Treaty and Imperative Lessons of Yoruba National Unity ${ }^{1}$
}

\author{
Stephen Banji Akintoye \\ Retired Professor \\ Department of History \\ University of Ife, Nigeria
}

I salute you, Your Royal Majesty, the Olubadan of Ibadan, our royal Father of this great occasion in the life of our Yoruba nation. I salute our beloved Governor and Host, Governor Seyi Makinde (of Oyo State). I salute the leaders, officers and members of the many organizations that have put today's occasion together. I salute all the eminent Yoruba men and women who have honored the invitation to this august occasion. I salute all our guests, friends, and well-wishers here gathered. Ladies and Gentlemen:

In the thousands of years of the pre-20 $0^{\text {th }}$ century history of the Yoruba nation, the Yoruba Peace Treaty of September 231886 is a unique document of incalculable importance. In modern Yoruba history, it is a foremost document that was deliberately designed to foster unity and peace among all parts of Yorubaland and among the entire Yoruba nation, Black Africa's largest nation, and Black Africa's foremost leader in civilization.

Representatives of virtually all kingdoms and ethnic sub-groups of the Yoruba nation appended their signatures to this treaty - from the Alaafin of Oyo to the Ooni and chiefs of Ife, the chiefs of Yorubaland's most powerful city of Ibadan, the kings and chiefs representing the large alliance known as the Ekitiparapo comprising the Ekiti, Ijesa, Igbomina and Akoko subgroups, the Awujale and war-chiefs of Ijebu.

Its terms and statements had something to say about virtually all parts of Yorubaland. Its immediate purpose was to bring to an end the Kiriji War, the war which had started between Ibadan and the Ekitiparapo in 1878, and which had expanded over the years to involve in various ways almost all other

1 Speech at the 2019 celebration of the 1886 Yoruba Peace Treaty at the House of Chiefs in Ibadan, Oyo State on 23 September 2019. 
kingdoms and states of Yorubaland - the Ooni's kingdom of Ife, the Modakeke kingdom near Ile-Ife, the Alaafin's kingdom of Oyo, the Awujale's kingdom of Ijebu, the Egba and Owu kingdoms of Abeokuta, the Remo kingdoms, the kingdom of Owo, the kingdom of Ondo, the kingdom of Ilorin, the kingdoms and communities of the Okun Yoruba in the Yoruba northeast, the kingdom of Lagos, the kingdoms of the Ilaje and the Ikale, even the far western Yoruba kingdoms of Ajase, Ketu and Sabe (now in Benin Republic).

The 1886 Treaty was a treaty affirming peace, brotherliness, friendship and commerce among all Yoruba people after nearly one-hundred years of internecine wars that had pitched Yoruba kingdoms against Yoruba kingdoms, cities against cities, and alliances against alliances, all over Yorubaland.

It is therefore a very positive development that we, today's generation of Yoruba people, have set aside the day of this Peace Treaty as a day to celebrate every year. In many locations in Yorubaland, this celebration is going on today. In future years, we must see to it that more and more locations in the Yoruba homeland, and even in the Yoruba Diaspora abroad, put up these September 23 celebrations of Yoruba unity.

As we gather here to celebrate, however, my humble thought is that we Yoruba should spend this day to rub minds together about some deeper ramifications of our nation's unity. Sure, we are a very strongly united nation. In fact, I have said in some of my past lectures and speeches that hardly any nation in the world can claim to be more united than our Yoruba nation. We Yoruba are all very proud of our culture and our great accomplishments in civilization. We believe that, among nations in the world, our nation is, and deserves to be, highly exalted because of the common worldview and the principles and ideals which we evolved in our history. Our religion is so superior in its overall message and its structure that it has become in the modern world the only Black African religion that ranks as a universal religion, one of the world's leading religions, one of the most widespread across the world, and one of the fastest expanding religions throughout the world.

Our nation is also owner of principles and ideals which command great respect in the world - principles and ideals such as our omolúàbi tenets, our deep respect for human life, our respect for individual peculiarities and choices, our generally democratic tendencies, our culture of religious accommodation and harmony, our deep sense of hospitality to strangers and foreigners, our unique expectation of dutiful, respectful and decent leadership and governance, our love of the beautiful and even elegant life, our unique dedication to societal progress and orderliness, and our general orientation towards mutual help and collaboration in the quest for the better life.

This worldview and these principles and ideals have kept our whole nation strongly bonded throughout our history. Even though we have lived in 
many separate kingdoms for most of our history, our common worldview and our cherished principles and ideals have made us a highly noticeable nation among the nations of Africa and the world. They have also distinguished us from other peoples near and far. Even when we fought wars in our nation for nearly a hundred years in the nineteenth century, the norms that we regard as uniquely Yoruba norms nevertheless strongly persisted.

The central focus of my speech today, however, is our significant failures to mobilize and employ our national unity on occasions when we desperately need to mobilize it most powerfully. In particular, at critical moments in our modern history since the last decade of the $19^{\text {th }}$ century, since the advent of British colonial rule, we have failed again and again to employ the strength inherent in our national unity to position our splendid nation for its victory and for its appropriate destiny in the world.

As we were ending the Kiriji War in 1886, we were already getting immersed into a new era in which our nation's inherent strength was experiencing very powerful reinforcements from new cultural inputs that were coming from another part of the world. Christian missions of various European nations had begun to come to our country and to the rest of Black Africa by the 1840s, bringing the Christian message and Western education. Because we Yoruba lived in heavily populated, secure, well ordered and well governed cities and towns, the Christian message and the Western education spread much faster in our country than in any other country in Africa. By the 1860s, we were already producing many university graduates in various disciplines.

By the 1880 s, we were already a nation with a strong and rapidly growing literate elite. We were also a nation with a considerable share in the growing worldwide commerce. We had many big Yoruba merchants in the new trade in the interior of our country and in our port towns. In fact, some of our coastal merchants had shipping lines of their own. In 1864, one of our clergymen was consecrated the Bishop of the Niger, becoming the leading Christian worker in most of West Africa. In 1859, the first newspaper in Africa began to publish in our city of Abeokuta and, in the years that followed, some other newspapers emerged in some of our other cities. Our Yoruba language was developed as a written language in these years, and a new culture of literature in the Yoruba language quickly evolved. From the late 1880s, the Yoruba modern elite created a powerful movement of Yoruba Cultural Nationalism, partly to strengthen Yoruba national unity, and partly to counter the cultural arrogance of Europeans in Africa - to demonstrate that Yoruba culture was not inferior, and was superior in many respects, to European cultures. No other Black African people developed a movement like this.

In short, a new and distinct nation-state or modern country of the Yoruba people was emerging undoubtedly out of West Africa. The roots of such a 
country were manifestly very strong. Its Yoruba people were powerfully unified by a common worldview, common cultural and ethical attributes, common national pride, common written language, a rapidly modernizing economy, and a strong and growing modern elite and middle class of professionals, entrepreneurs, and visionaries. We were the largest single Black African indigenous nation, were highly advanced in civilization, and were a powerful nation. In the wide world outside of Europe, we Yoruba nation had much more readiness than almost all other nations to be a separate modern country on our own. The Japanese unified their country in these times and created the modern nation-state of Japan, but by the 1870s, the Japanese were not nearly as ready as we Yoruba were for that kind of historic accomplishment.

We need therefore to ask ourselves some very serious questions today. It is, I believe, very instructive that most of these questions are questions that generations of my Yoruba undergraduate students have asked me during my long career as a university teacher. Why did we fail to grab our nation as a separate entity when European imperialism was beginning to sweep over West Africa? Why did we fail to do so - even if we would agree ultimately to become a country under British rule? The small nation of the Basuto in Southern Africa managed to stay intact and separate in those circumstances, even though it ultimately accepted British imperial rule. Why couldn't we Yoruba exploit our unity and strength to do at least that? Why did we - large, strong, educated and rich nation - allow our nation under British colonialism to be dragooned into an amalgamation with hundreds of other nations into a large and incoherent country that was manifestly likely to be unmanageable? Even though the British, out of fear of us, did all sorts of things to depress and distort our image in Nigeria in colonial times, why have we, since independence, allowed ourselves to be dragged further and further down by Nigeria? Why do we let ourselves be imposed upon, and be relentlessly pushed towards a noxious destiny, by some small and less accomplished nationality in the context of independent Nigeria?

At this point in time when our nation and most other Nigerian nationalities have been reduced to the status of near slavery in Nigeria, what ought to be the Yoruba nation's manly response? A shrouded federal establishment controls almost all powers and resources in Nigeria, almost totally monopolizing all command positions in the hands of one small nationality, continually seeking with impunity to seize more and more powers and resources, reducing the homelands of most Nigerian nationalities to disrespected, subdued and distressed peripheries in Nigeria, reducing the elected state governments of most Nigerian peoples into impotent and timid leaders of their peoples, treating the citizens of the subdued nationalities who get to serve in 
the federal establishment as persons who hold their positions there by sufferance and tolerance only, and, in all these ways, generating deeper and deeper levels of poverty, insecurity, instability and hopelessness in Nigeria.

Above all these, in recent years, members the small nationality that controls the powers and resources of the Federal Government has launched an invasion on the rest of Nigeria, threatening to kill, maim and destroy, and actually killing, maiming and destroying, and bringing large numbers of their non-Nigerian ethnic kinsmen to help them, in an ethnic cleansing campaign that is aimed at permanently seizing the land and other resources of all other peoples of Nigeria.

In these conditions and circumstances, the masses of the people, youths, women and children of the large and resourceful Yoruba nation want to know what the leadership of their nation will do, and the peoples of the other nationalities of Nigeria, and decent people all over the world, want to know too.

In one of my recent speeches, I pointed to a particular occasion in which the Yoruba nation commanded enormous resources of power but failed to gather the resources together to defend its country. I refer to the British invasion of Ijebu in 1892. When the British invaders came, the Ijebu bravely raised a large and well-armed force to face them. And the Ijebu forces seemed about to win, until the invaders rushed up some categories of weapons which the Ijebu did not yet have. But at that time when the Ijebu were losing that engagement, the Yoruba nation commanded more than enough military capability to prevent any part of their homeland from being conquered.

Had some of the large power of the Yoruba nation been gathered to support the Ijebu, the Ijebu could not possibly have lost. All the well-armed and war-seasoned armies owned by various Yorùbá authorities as a result of the $19^{\text {th }}$ century Yoruba wars were overwhelming. If they had worked together, they were more than enough to warn off, or defeat, the British invaders. İbàdàn had an army numbering 80,000 at İgbájọ and İkìrun, another numbering about 40,000 near Abẹòkúta, another numbering about 30,000 at Orù in Rẹmọ, and yet another numbering about 30,000 near Ifẹ and Modákẹ́kẹ́. The Ėkìtiparapọ had an army numbering 50,000 near Imèsí-Ilé, and another numbering 25,000 near Ilé-Ifẹ. İlọrin had an army of about 15,000 near Ộfà.

Beyond the immediate war fronts, Ife had an army of about 30,000 in the Ifệtẹ dó and Òkè-Igbó area; and On'dó had an army of about 35,000 near Òkè-Igbó. The kingdoms of İjẹ̉bú-Òde, Abẹòkúta, Ộwọ̀ and Kétu (Ketu now in Benin Republic) had forces that were reputed to be among the best armed in the country. The İjẹbú-Òde kingdom had a main army numbering about 60,000 , another numbering about 40,000 near Orù, and another numbering about 25,000 near Ilé-Ifẹ. Abẹòkúta’s army numbered about 50,000; Ờwọ’s about 40,000; and Kétu's army about 40,000. Thus, together, the Yorùbá 
Nation commanded over 500,000 fairly well-armed and highly seasoned troops commanded by very seasoned generals. This was a much bigger and better force than was owned by any other African nation at the time, and a much bigger and better force than the European invaders ever encountered anywhere in Africa. But these Yoruba forces were never pulled together. And as a result, relatively small armies commanded by mostly inexperienced European officers conquered parts of Yorùbáland.

Moreover, Yoruba capabilities at the time did not end with military power. The influence of the Yoruba elite was considerable. Used to Influence the governments of European countries, it might have saved Yorubaland from becoming part of the empire of any European nation in Africa. The influence of the Yoruba clergy in Church circles in Europe was also considerable. And so was the influence of Yoruba merchant companies and Yoruba-owned newspapers. In short, the Yorùbá Nation had a great deal of power at its command but failed to harness it together to defend itself.

Therefore, the greatest and final question before the Yoruba people today is as follows: In the face of coordinated assaults on Yoruba farmlands, cities and towns and highways by the Fulani, will the Yoruba fail again to harness the enormous and variegated resources of power at their disposal for the defense and liberation of their homeland and their people?

My in-depth knowledge and perception of Yoruba readiness today is clear and unambiguous. The Yoruba will fully and absolutely use their great power. They will fight and win. And they will set their homeland and their people completely free once and for all.

I must now send a number of messages. The first is a message from the entire Yoruba nation at home and abroad to those who are designing evil against our land and people. We hear your horrid threats. We hear you threatening that you will come to kill, to maim and to destroy in our land. We see you already coming into our ancestral homeland and brutalizing some of our people and on our farms, villages, and highways. We are fully aware that your ultimate intention is to launch a wholesale and coordinated assault to envelope our whole nation in massive destruction. And we want you to know that we are more than ready to crush you and completely throw you out of our land.

The second is a message from this Yoruba Day celebration to every Yoruba man, woman and child. Do not run before the marauders. Never abandon any part of your farm or farmland or highway or city or town to any of them. Learn to join hands and to pull your resources of power together to throw the invaders out of our land, our farms, our villages, our towns and our cities. Use whatever you can lay your hands upon to defend yourselves, your loved ones and your communities. Keep standing and fighting bravely until help comes. 
In this desperate emergency, let us all defend our nation rather than our parties and organizations. Let the spirit of the proud victory of 1840 guide and inspire you.

Never forget that we Yoruba are a great and powerful nation, one of the largest, greatest and most powerful indigenous nations of Black Africa. Do not forget that our nation's power is spread out widely into all corners of the world. We do not desire to hurt or subdue any other nation or to take their land. But we will never let any other nation take any inch of our land. We stand on the solid footing that our cause is just. We stand tall and strong. The sword of the just, the eternal Sword of Victory, goes ahead of us. Oduduwa himself beckons us to a great victory.

The third message is to all the civic organizations that have been standing bravely forward to defend our land. It is a message to the indomitable Odua Peoples Congress, OPC, to the young and brave warrior, Gani Adama, who holds the ancient Sword as our nation's Aare Ona Kakanfo, to the ever-victorious Agbekoya, Yorubakoya, Yoruba Liberation Command, Okun Youth Association, Odua United Yoruba Kingdom, to the tens of our other self-determination groups, and to the countless warriors who, as individuals or local groups, defend our Yorubaland day and night. We know your worth. We are confident that with you standing out there, our Yoruba nation can laugh in the face of any invader.

And the final message is a message from this gathering on behalf of all our Yoruba people at home and abroad to all our State Governors. We all, irrespective of our political party affiliations, appreciate and thank you, our State Governors, for all that you are doing to defend our homeland. We are happy that you have joined hands together and are working together on this historic task. We are all standing solidly behind you to see all threats to the peace and security of our homeland cleared away.

I must conclude now with a quotation from my speech to Egbe Omo Yoruba of United States and Canada in their $25^{\text {th }}$ Anniversary in Baton Rouge, Louisiana, USA, on $19^{\text {th }}$ July this year. "My summary of all the pictures of the Nigerian and Yoruba scene today is that we, the present generation of Yoruba leaders, have great duties that urgently demand our responses. A great American leader once said, "To some generations much is given; of other generations much is expected". It is my profound belief that we of today's generation of Yoruba people are called upon to give much to our Yoruba nation, to the Black Race, and to the world. It is my profound belief that we do have much to give. And it is my profound belief that we will bravely give it".

I thank you all. 